Acta vet. scand. $1974,15,356-365$.

From the Department of Pharmacology and Toxicology, Royal Veterinary and Agricultural University, Copenhagen, Denmark.

\title{
HALF-LIVES OF SULPHADOXINE AND TRIMETHOPRIM AFTER A SINGLE INTRAVENOUS INFUSION IN COWS*
}

\author{
By \\ Danis Davitiyananda** and Folke Rasmussen
}

\begin{abstract}
DAVITIYANANDA, DANIS and FOLKE RASMUSSEN: Half-lives of sulphadoxine and trimethoprim after a single intravenous infusion in cows. Acta vet. scand. 1974, 15, 356-365. - The half-life of sulphadoxine in plasma (11 hrs.) is much longer than that of trimethoprim (50-103 min.) and in accordance to this traces of sulphadoxine are demonstrated in the milk 3 days after the infusion, while trimethoprim could not be detected in milk 2 days after the infusion. The apparent volume of distribution is 0.37 for sulphadoxine and 1.14 for trimethoprim, i.e. $37 \%$ and $114 \%$ of the body weight, respectively.

sulphadoxine; trimethoprim; half-life; cow.

In continuation of the investigations on the mammary and renal excretion of trimethoprim and sulphadoxine in goats (Rasmussen 1970, Jørgensen 1972, Jørgensen \& Rasmussen 1972) and cows (Davitiyananda \& Rasmussen 1974) it was of interest to know how these excretory mechanisms influence the concentrations of the drugs obtained after intravenous infusion of therapeutically adequate doses in cows.
\end{abstract}

\section{MATERIALS AND METHODS}

On 7 cows weighing $350-500 \mathrm{~kg}, 7$ experiments with sulphadoxine and trimethoprim and 2 experiments with sulphadoxine alone were performed. A clinical examination indicated that the

- Supported by the Danish Agricultural and Veterinary Research Council.

* On leave from the Department of Pharmacology, Veterinary Faculty, Bangkok, Thailand. 
cows were healthy, non-pregnant and the udders were normal. The milk yield varied from 3 to $8 \mathrm{~kg}$ per day. Sulphadoxine (40 $\mathrm{mg} / \mathrm{kg}$ b.wt.) and trimethoprim ( $8 \mathrm{mg} / \mathrm{kg} \mathrm{b.wt.)}$ as Trivetrin ${ }^{\circledR}$ * were administered intravenously. Blood samples were collected every half hour for the first 2 hrs. after infusion and then every or every second hour for the following $4 \mathrm{hrs}$. and in the morning and afternoon of the following days. Milk samples were collected 2 and $6 \mathrm{hrs}$. after the infusion and then in the morning and afternoon of the following days.

Sulphadoxine in blood plasma, urine and milk was measured ad modum Bratton \& Marshall (1939) for milk, modified by Rasmussen (1958). Trimethoprim was estimated according to the method of Schwartz et al. (1969).

The protein-binding of sulphadoxine and trimethoprim in blood plasma and milk was determined by ultrafiltration by the method of Poulsen (1956). The cellophane membrane used was "Kalle" dialysing tube, diameter $32 \mathrm{~mm}$, pore size 20-80 $\mathrm{A}$, permitting molecules with a molecular weight up to 5,000 to pass through.

The apparent volume of distribution was determined according to Butler (1971) from the formula

$$
\mathrm{V}_{\mathrm{d}}=\frac{\mathrm{Q}}{\mathrm{c}}
$$

where $Q$ is the dose expressed in $\mathrm{mg} / \mathrm{kg}$ b.wt. and $\mathrm{c}$ is the concentration in plasma $(\mathrm{mg} / \mathrm{l})$ at zero time. $V_{d}$ will then be a ratio that can be considered a proportion of the body weight.

The statistical calculations were done in accordance to standard methods (Kemp 1955), and the results are given as average \pm s.e.m.

\section{RESULTS}

Concentrations of sulphadoxine and trimethoprim in plasma and milk

Fig. 1 shows the results obtained after a single intravenous infusion. The concentration of non-acetylated sulphadoxine in plasma 30 min., 6 hrs. and 48 hrs. after the infusion was 160 $\mu \mathrm{g} / \mathrm{ml}, 79 \mu \mathrm{g} / \mathrm{ml}$ and $10 \mu \mathrm{g} / \mathrm{ml}$, respectively, while the concentration of trimethoprim at $30 \mathrm{~min}$. and $6 \mathrm{hrs}$. was $5 \mu \mathrm{g} / \mathrm{ml}$ and $0.6 \mu \mathrm{g} / \mathrm{ml}$.

* Trivetrin® and sulphadoxine were generously supplied from the Wellcome Research Laboratories, Beckenham, Kent, England. 


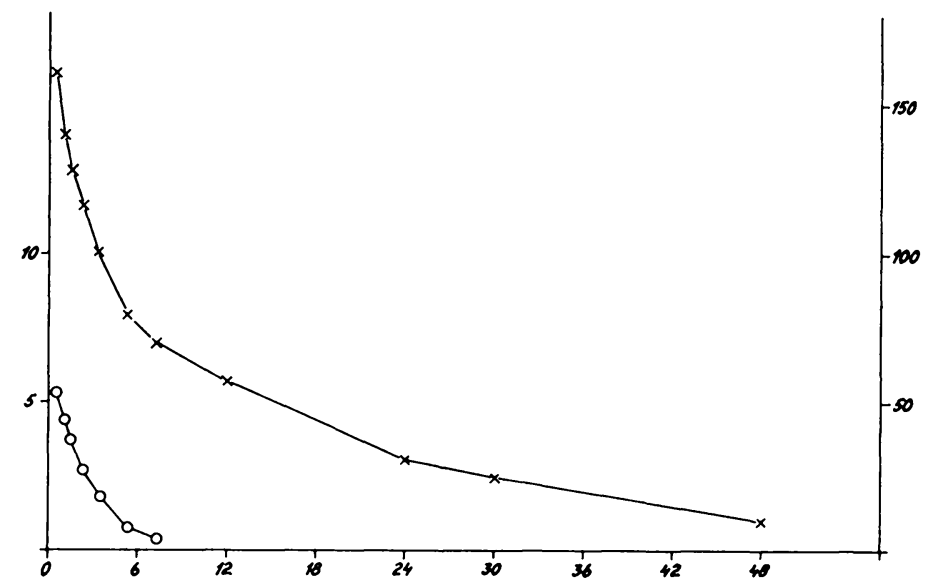

Figure 1. Concentrations of sulphadoxine and trimethoprim in plasma after a single intravenous infusion of $40 \mathrm{mg}$ sulphadoxine and $8 \mathrm{mg}$ trimethoprim (Trivetrin $\AA$ ) per $\mathrm{kg} \mathrm{b.wt.}$

Ordinate on the left: Concentration of trimethoprim $(\mu \mathrm{g} / \mathrm{ml})$. Ordinate on the right: Concentration of sulphadoxine $(\mu \mathrm{g} / \mathrm{ml})$.

Abscissa: Time in hours.

$\mathbf{x}-\mathrm{x}$ : Sulphadoxine in plasma.
$\mathbf{0}-\mathrm{o}$ : Trimethoprim in plasma.

The protein-bound fraction of sulphadoxine in plasma varied from $44-51 \%$ at concentrations above $150 \mu \mathrm{g} / \mathrm{ml}$ to $65-80 \%$ at concentrations below $50 \mu \mathrm{g} / \mathrm{ml}$. The concentration of sulphadoxine in milk was much lower than in plasma, and the highest concentration in milk was $32 \mu \mathrm{g} / \mathrm{ml}$ measured 6-7 hrs. after administration (Table 1 ). In milk $0-28 \%$ of the sulphadoxine was bound to the proteins. Only minor amounts of $\mathrm{N}^{4}$-acetylated sulphadoxine were found in plasma and milk i.e. less than $8 \%$ and $14 \%$, respectively. Traces of sulphadoxine were found in both plasma and milk from 3 cows 3 days after the infusion.

The concentrations of trimethoprim in milk (Table 1) were equal to or higher than in plasma. The binding of trimethoprim to the proteins was a little higher in plasma $(46-73 \%)$ than in milk $(25-50 \%)$. Twenty-four hrs. after the infusion traces of trimethoprim were found in most cases in both plasma and milk (Table 1), while trimethoprim could not be demonstrated in samples taken $48 \mathrm{hrs}$. after the infusion. 
T able 1. Concentrations of sulphadoxine and trimethoprim in plasma and milk after a single intravenous infusion.

\begin{tabular}{|c|c|c|c|c|c|c|c|c|c|c|c|c|}
\hline \multirow{3}{*}{$\begin{array}{l}\text { Cow } \\
\text { no. }\end{array}$} & \multicolumn{4}{|c|}{2 hrs. after inf. } & \multicolumn{4}{|c|}{ 6-7 hrs. after inf. } & \multicolumn{4}{|c|}{24 hrs. after inf. } \\
\hline & \multicolumn{2}{|c|}{ sulph. } & \multicolumn{2}{|c|}{ TMP } & \multicolumn{2}{|c|}{ sulph. } & \multicolumn{2}{|c|}{ TMP } & \multicolumn{2}{|c|}{ sulph. } & \multicolumn{2}{|c|}{ TMP } \\
\hline & $\mathbf{p}$ & $\mathbf{m}$ & $\mathbf{p}$ & $\mathbf{m}$ & $\mathbf{p}$ & $\mathbf{m}$ & $\mathbf{p}$ & $\mathbf{m}$ & $\mathbf{p}$ & $\mathbf{m}$ & $\mathbf{p}$ & $\mathbf{m}$ \\
\hline 1 & 131 & 20 & 2.9 & 7.7 & 92 & 16 & 0.3 & 3.7 & 48 & 3 & 0.2 & trace \\
\hline 2 & 119 & 28 & 1.7 & 4.4 & 79 & 32 & 0.1 & 0.8 & 27 & 4 & trace & 0.3 \\
\hline 3 & 110 & 28 & 1.1 & 2.5 & 66 & 11 & 0.3 & 0.3 & 8 & 2 & trace & trace \\
\hline 4 & 119 & 24 & 2.6 & 5.0 & 79 & 24 & 0.7 & 2.0 & 31 & 2 & trace & $\mathbf{0}$ \\
\hline 5 & 128 & 26 & 3.2 & 4.9 & 84 & 13 & 0.7 & 2.1 & 33 & 5 & trace & trace \\
\hline 6 & 100 & 13 & 3.5 & 10.0 & 60 & 10 & 0.7 & 2.0 & 8 & trace & trace & trace \\
\hline 6 & 113 & 9 & - & - & 75 & 8 & - & - & 22 & trace & - & - \\
\hline 7 & 100 & 15 & 2.2 & 10.0 & 62 & 9 & 0.1 & 0.3 & 21 & trace & 0 & 0 \\
\hline 7 & 107 & 16 & 一 & - & 82 & 11 & - & - & 19 & trace & - & - \\
\hline
\end{tabular}

p: plasma.

m: milk.

Sulphadoxine and trimethoprim half-life in plasma

On account of the above mentioned experiments the half-life for sulphadoxine and trimethoprim was calculated, and the results from a single experiment are given in Fig. 2, while Table 2 summarizes the results obtained in 9 experiments. From Fig. 2 (the same experiment as Fig. 1) it is seen that the disappearance from plasma of sulphadoxine followed a curve which is the result

T a b l e 2. The half-lives for sulphadoxine and trimethoprim in min. after intravenous infusion.

\begin{tabular}{cccc}
\hline \multirow{2}{*}{ Cow no. } & \multicolumn{2}{c}{ Sulphadoxine } & Trimethoprim \\
\cline { 2 - 3 } & $\begin{array}{c}\text { up to } 4 \text { hrs. } \\
(\alpha \text {-slope })\end{array}$ & $\begin{array}{c}\text { between } 4 \text { and } 48 \text { hrs. } \\
(\beta \text {-slope })\end{array}$ & \\
\hline 1 & 45 & 896 & 103 \\
2 & 50 & 597 & 54 \\
3 & 35 & 378 & 55 \\
4 & 66 & 838 & 97 \\
5 & 70 & 805 & 78 \\
6 & 52 & 640 & 60 \\
6 & 50 & 605 & 50 \\
7 & 57 & 520 & - \\
7 & 65 & 548 & $71 \pm 8$ \\
average \pm s.e.m. & $54 \pm 4$ & $647 \pm 56$ & 1 hr. 11 min. \\
hrs. and min. & 54 min. & 10 hrs. 47 min. & \\
\hline
\end{tabular}




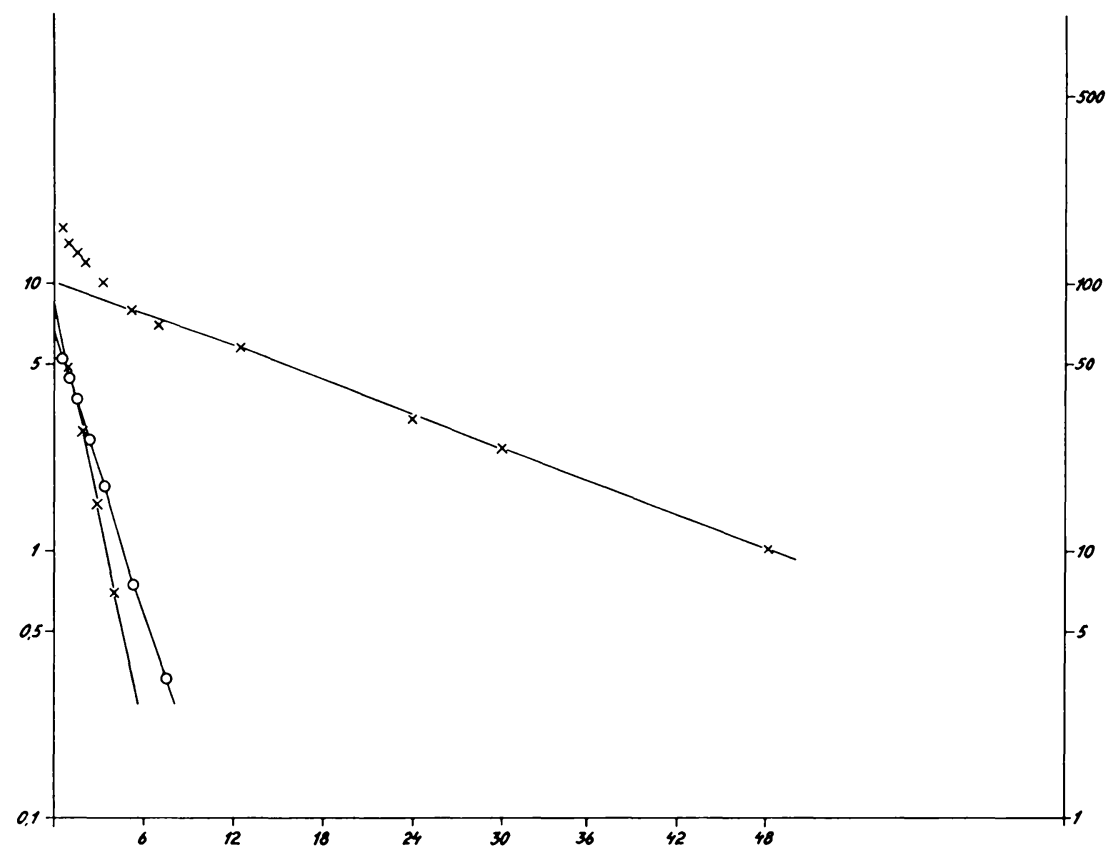

F i g u r e 2. Half-life curves for sulphadoxine and trimethoprim from plasma. The same experiment and signatures as in Fig. 1.

Ordinate on the left: Concentration of trimethoprim (log. scale). Ordinate on the right: Concentration of sulphadoxine (log. scale). Abscissa: Time in hours.

of 2 exponential functions initially one with a half-life of $66 \mathrm{~min}$. $(\alpha$-slope) and later on one with a half-life of $838 \mathrm{~min}$. ( $\beta$-slope). The simultaneously estimated half-life for trimethoprim followed a single exponential function and the half-life was $97 \mathrm{~min}$. In 7 experiments the half-life for trimethoprim was $71 \pm 8 \mathrm{~min}$. (Table 2). Further, Table 2 shows that the initial half-life for sulphadoxine in average of 9 experiments was $54 \pm 4 \mathrm{~min}$., while the half-life calculated on observations in the period from 4 to 48 hrs. after the infusion was on an average $647 \pm 56 \mathrm{~min}$.

\section{A pparent volume of distribution}

From the half-life estimations the concentration of drug in plasma at zero time can be calculated. These zero time concentrations were in average $109 \mathrm{mg} / \mathrm{l}$ and $7 \mathrm{mg} / \mathrm{l}$ for sulphadoxine ( $\beta$-slope) and trimethoprim, respectively, and the apparent volume of distribution was 0.37 for sulphadoxine and 1.14 for trimethoprim. 


\section{DISCUSSION}

The results show, that sulphadoxine is greatly bound to plasma proteins especially at low concentrations, which agrees with the findings in goats (Jørgensen 1972, Jørgensen \& Rasmussen 1972). The binding of trimethoprim to plasma proteins is a little higher than in goats (Rasmussen 1970). However, the experiments on goats (Rasmussen 1970) are in most cases done at concentrations of trimethoprim far higher than the concentrations of trimethoprim in plasma from cows. The binding of trimethoprim is of the same order as found by Craig \& Kunin (1973) in humans, while Bushby \& Hitchings (1968) and Schwartz \& Ziegler (1969) found that only between 30 and $46 \%$ of trimethoprim was bound to proteins in human plasma. After a single intravenous infusion there are very big differences in the disappearance of sulphadoxine and trimethoprim from plasma (Figs. 1 and 2 ). The results in Fig. 2 show that the concentrations of sulphadoxine in plasma plotted semilogarithmically versus time fit in with 2 linear regression lines which means that there is an initial short half-life which mainly reflects the distribution of sulphadoxine from plasma into the body tissues. This initial half-life is on an average $54 \mathrm{~min}$. ( $\alpha$-slope), while the second half-life mainly reflects the elimination and is much longer, on an average $647 \mathrm{~min}$. ( $\beta$-slope, Table 2 ). However, the half-life of sulphadoxine in cows ( $11 \mathrm{hrs}$.) is much shorter than in man (205 hrs., Madsen \& Iversen 1964; 150 hrs., Struller 1968; 179 hrs., Böhni et al. 1969). The half-life of trimethoprim in cows is just around $1 \mathrm{hr}$. and thus much shorter than the half-life in man (12 hrs., Bushby \& Hitchings 1968, Bergan \& Brodwall 1972, Nolte \& Büttner 1973; 10 hrs., Schwartz \& Ziegler; 9 hrs., Schwartz \& Rieder 1970, Craig \& Kunin 1973). The half-lives of sulphadoxine and trimethoprim in cows compared with the halflives in man underline the great variations which can occur between species. The short half-lives in cows indicate a fast elimination i.e. excretion and metabolism of sulphadoxine and trimethoprim. Especially the metabolic rate of trimethoprim seems to be important in ruminants (Nielsen \& Rasmussen 1972).

The apparent volume of distribution of sulphadoxine (0.37) is equal to that of sulphabenzpyrazine (Stowe et al. 1957) and sulphamethylphenazole (Tschudi 1973) in cows. Taking the factors which can influence the estimation of the apparent volume of distribution into consideration (Butler 1971) the results in- 
dicate that sulphadoxine is distributed in intracellular water only to some extent. The apparent volume of distribution of trimethoprim (1.14) is 3 times greater than that of sulphadoxine and indicates distribution throughout the total body water and further that trimethoprim is concentrated in some tissues. The apparent volume of distribution of trimethoprim in cows seems to be a little lower than in humans (1.4, Schwartz \& Rieder, Nolte \& Büttner; 2, Bergan \& Brodwall).

The large volume of distribution for trimethoprim indicates higher concentrations in tissues than in blood plasma which is also found in rats (Bushby \& Hitchings, Schulz 1972), pigs, goats and cows (Nielsen \& Rasmussen 1974).

Principally one should avoid fixed combinations of drugs, but in a few cases there can be a theoretical background for a combination such as the pronounced synergism between trimethoprim and sulphonamides (vide Reisberg et al. 1966, Bisping 1970, Bushby 1969, Böhni 1969, Barnett \& Bushby 1970, Rasmussen 1971). To obtain the maximal antibacterial synergism it must be an advantage to combine compounds with half-lives of the same range or adjust the dosage of each drug in accordance to their pharmacokinetics. In human medicine trimethoprim is combined with sulphamethoxazole $(1: 5)$ both having half-lives of the same range (Bergan \& Brodwall, Craig \& Kunin). One of the suggested combinations in the veterinary clinic is trimethoprim and sulphadoxine (1:5) (vide Rehm \& White 1970, White $\&$ Withnell 1973). Judged by the big difference in the half-lives of trimethoprim and sulphadoxine this combination seems not to offer the best possibilities for optimal synergism in ruminants. Although the big volume of distribution of trimethoprim indicates higher concentrations of trimethoprim in tissues than in blood plasma it should be possible to find more suitable sulphonamides for such combinations intended for treatment of infections in ruminants.

\section{REFERENCES}

Barnett, Margaret \& S. R. M. Bushby: Trimethoprim and the sulphonamides. Vet. Rec. 1970, 87, 43-51.

Bergan, T. \& E. K. Brodwall: Human pharmacokinetics of a sulfamethoxazole-trimethoprim combination. Acta med. scand. 1972, 192, 483-492.

Bisping, W.: In-vitro-Untersuchungen zur Potenzierung der Sulfonamidwirkung durch Trimethoprim. (An in-vitro study of the 
potentiation of sulphonamides by trimethoprim). Dtsch. tierärztl. Wschr. 1970, 77, 511-515.

Bratton, A.C.\&E.K. Marshall: A new coupling component for sulphanilamide determination. J. biol. Chem. 1939, 128, 537-550.

Bushby, S. R. M.: Combined antibacterial action in vitro of trimethoprim and sulphonamides. Postgrad. med. J. 1969, 45, suppl., 10 - 18.

Bushby, S. R. M. \& G. H. Hitchings: Trimethoprim, a sulphonamide potentiator. Brit. J. Pharmacol. 1968, 33, 72-90.

Butler, T.: The distribution of drugs. In B. N. LaDu, H. G. Mandel \& E. L. Way: Fundamentals of Drug Metabolism and Drug Disposition. Williams \& Wilkins Comp., Baltimore 1971.

Böhni, Erika: Chemotherapeutic activity of the combination of trimethoprim and sulphamethoxazole in infections in mice. Postgrad. med. J. 1969, 45, suppl., 18-21.

Böhni, Erika, B. Fust, J. Rieder, K. Schaerer \& L. Havas: Comparative toxicological, chemotherapeutic and pharmacokinetic studies with sulphormethoxine and other sulphonamides in animals and man. Chemotherapy (Basel) 1969, 14, 195-226.

Craig, W. A. \& C. M. Kunin: Trimethoprim-sulfamethoxazole: Pharmacodynamic effects of urinary $\mathrm{pH}$ and impaired renal function. Ann. intern. Med. 1973, 78, 491—497.

Davitiyananda, D. \& Folke Rasmussen: Mammary and renal excretion of sulphadoxine and trimethoprim in cows. Acta vet. scand. 1974, 15, 340-355.

Jørgensen, Sigrid Tue: Mammær ekskretion hos geder af sulfadoxin og sulfamethoxazol sammenlignet med sulfanilamid og sulfadimidin. (Mammary excretion in goats of sulphadoxine and sulphamethoxazole compared with sulphanilamide and sulphadimidine). Nord. Vet.-Med. 1972, 24, 1-10.

Jørgensen, Sigrid Tue \& Folke Rasmussen: Renal ekskretion af sulfanilamid, sulfadimidin, sulfadoxin og sulfamethoxazol hos geder. (Renal excretion of sulphanilamide, sulphadimidine, sulphadoxine and sulphamethoxazole in goats). Nord. Vet.-Med. 1972, $24,601-611$.

Kemp, T.: Statistik for medicinere. (Statistics for physicians). Munksgaard, København 1955.

Madsen, S. T. \& P. F. Iversen: Metabolic problems during treatment with longacting sulfonamides. III Int. Congr. Chemotherapy (July 1963), 1964, 644-648.

Nielsen, P. \& Folke Rasmussen: Elimination of trimethoprim in pigs and goats. Acta pharmacol. (Kbh.) 1972, Suppl. I, 31, 94.

Nielsen, P. \& Folke Rasmussen: Trimethoprim and sulphadoxine in swine. Half-lives, volume of distribution and tissue concentration. 1974. To be published. 
Nolte, $H . \& H$. Büttner: Pharmacokinetics of trimethoprim and its combination with sulphamethoxazole in man after a single and chronic oral administration. Chemotherapy (Basel) 1973, 18, 274-284.

Poulsen, E.: Renale clearanceunders $\varnothing$ gelser hos køer. (Renal clearance in cows). Thesis, C. Fr. Mortensen, København 1956.

Rasmussen, Folke: Mammary excretion of sulphonamides. Acta pharmacol. (Kbh.) 1958, 15, 139-148.

Rasmussen, Folke: Renal and mammary excretion of trimethoprim in goats. Vet. Rec. 1970, 87, 14-18.

Rasmussen, Folke: In vitro antibacterial activity of trimethoprim and sulphonamides on bacteria causing bovine mastitis. Acta vet. scand. 1971, 12, 131-133.

Rehm, W. F. \& G. White: A field trial with a trimethoprim/sulphonamide combination in bacterial diseases of cattle and pigs. Vet. Rec. $1970,87,39-42$.

Reisberg, B., J. Herzog \& L. Weinstein: In vitro antibacterial activity of trimethoprim alone and combined with sulphonamides. Antimicrob. Agents Chemother. 1966, 6, 424-429.

Schulz, R.: Distribution and elimination of trimethoprim in pregnant and newborn rats. Naunyn-Schmiedeberg's Arch. Pharmacol. 1972, 272, 369-377.

Schwartz, D. E. \& J. Rieder: Pharmacokinetics of sulfamethoxazole + trimethoprim in man and their distribution in the rat. Chemotherapy (Basel) 1970, 15, 337-355.

Schwartz, D. E. \& W. H. Ziegler: Assay and pharmacokinetics of trimethoprim in man and animals. Postgrad. med. J. 1969, 45, suppl., $32-37$.

Schwartz, D. E., B. A. Koechlin \& R. E. Weinfeld: Spectrofluorimetric method for the determination of trimethoprim in body fluids. Chemotherapy (Basel) 1969, 14, suppl., 22-29.

Stowe, C. M., D. Pallesen \& $W$. Hartman: Studies on the pharmacology of sulfaquinoxaline in dairy cattle. Amer. J. vet. Res. 1957, 43, $511-518$.

Struller, Th.: Progress in sulfonamide research. Fortschr. Arzneimittelforsch. 1968, 12, 390-451.

Tschudi, P.: Elimination, Plasmaproteinbindung und Dosierung einiger Sulfonamide. II. Untersuchungen beim Rind. (Excretion, plasma-protein binding and dosage of some sulphonamides. II. Studies in cattle). Zbl. Vet. Med. A. 1973, 20, 145-154.

White, G. \& C. G. Withnell: Chemotherapeutic evaluation of trimethoprim and sulphonamides in experimental salmonellosis of sheep. Res. vet. Sci. $1973,14,245-254$. 


\section{SAMMENDRAG}

Halveringstiderne for sulfadoxin og trimethoprim efter en enkelt intraven $\phi s$ infusion på køer.

Halveringstiden for sulfadoxin i blodplasma $\left(t_{\frac{1}{2}}=11\right.$ timer $)$ er meget længere end halveringstiden for trimethoprim (50-103 min.). I overensstemmelse med dette påvistes der spor af sulfadoxin i mælken i 3 dage efter infusionen, mens der ikke kunne påvises rester af trimethoprim i mælken 2 dage efter infusionen. Fordelingsvolumnet er 0.37 for sulfadoxin og 1.14 for trimethoprim, d.v.s. henholdsvis $37 \%$ og $114 \%$ af legemsvægten.

(Received January 15, 1974).

Reprints may be requested from: Folke Rasmussen, Department of Pharmacology and Toxicology, Royal Veterinary and Agricultural University, Bülowsvej 13, DK-1870 Copenhagen V, Denmark. 